\title{
Expression of Clostridium thermocellum Endoglucanase Gene in Lactobacillus bulgaricus and Lactobacillus plantarum and in vitro Survival Characteristics of the Transformed Lactobacilli
}

J. S. Cho*, S. H. Kang*, H. G. Lee*, H. J. Lee**, J. H. Woo***, Y. S. Moon****,

$$
\text { C. J. Yang***** and Y. J. Choi* }
$$

School of Agricultural Biotechnology, Seoul National University*, National Livestock Research Institute, RDA,** Laboratory of Molecular Biology, National Institute of Mental Health, Bethesda, Maryland 20892, USA***,

Department of Animal Science and Biotechnology, Jinju National University****,

Department of Animal Science and Technology, Sunchon National University*****

\author{
Lactobacillus bulgaricus와 Lactobacillus plantarum 균주에서 \\ Clostridium thermocellum 유래 endoglucanase의 발현과 \\ 발현 유산균의 in vitro 생존 특성 \\ 조재순*.강승하*.이홍구*.이현준**.우정희 $* * *$ 문양수****.양철주*****.최윤재* \\ 서울대학교 농생명공학부*, 농촌진흥청 축산기술연구소**, 미국 메릴렌드주 국립보건원***, \\ 진주산업대학교 동물생명과학과****, 순천대학교 동물자원과학과*****
}

\begin{abstract}
Endoglucanase A from Clostridium thermocellum which is resistant to pancreatic proteinase was selected out of numbers cellulases then were expressed in lactobacilli. Recombinant lactobacilli expression vector, pSD1, harboring the endoglucanase gene from $C$. thermocellum under the control of its own promoter, was constructed. Both L. bulgaricus and L. plantarum were electrotransformed with pSD1. The endoglucanase activities of 0.120 and $0.144 \mathrm{U} / \mathrm{ml}$ were found in culture media of $L$. bulgaricus and L. plantarum containing pSD1, respectively. In vitro survival characteristics of the transformed lactobacilli were tested. Both L. bulgaricus and L. plantarum showed a similar resistance to low $\mathrm{pH}$ 3. Moreover, L. plantarum was bile-salt resistant in the presence of 0.3 and $1 \%$ oxgall. $L$. bulgaricus and L. plantarum showed a rather homogenous resistant pattern against the tested antibiotics. Both of the strains were resistant to amikacin, gentamicin, streptomycin, kanamycin, and colistin.
\end{abstract}

(Key words : Endoglucanase activity; Clostridium thermocellum; Survival of Lactobacilli)

\section{I . INTRODUCTION}

Lactobacillus species are normal inhabitants of the gastrointestinal tracts of the mammalians and are main constituents of probiotics which are fed to newborn livestock with the aim of enhancing 
the immune system, increasing body weight gain, and improving feed conversion rates (Abe et al., 1995). Recently, it was suggested that more efficacious probiotics could be developed through the genetic modification of gastrointestinal strains of lactobacilli (Tannock, 1992). The modified strains would colonize in the digestive tract when the animal hosts consume and synthesize a novel product (Heng et al., 1997). But, so far, the development of genetically modified lactobacilli has been proved difficult, largely because suitable plasmid expression cassettes with strong promoters and signal sequences of Lactobacillus origin have not yet been established.

In mono-gastric animal, the major plant cell wall components of cereals, primarily $\beta$-glucans and arabinoxylans, form gel-like structures in the small intestines, trap nutrients, and therefore hinder enzymatic hydrolysis and absorption(Hall et al., 1993). The viscous polysaccharides can also cause severe gastrointestinal disorders (Hall et al., 1993). To improve the performances of non-ruminant animals, barley-based diets are often supplemented with endoglucanases and endoxylanases, particularly in poultry. However, enzyme supplementation substantially increases the cost of feed and thus is only used as a short-term solution in enhancing digestion of cereals. An alternative and less expensive strategy should be designed to develop lactobacilli with the capacity to digest plant structural carbohydrates by the introduction of heterologous genes encoded by polysaccharide-degrading enzymes.

The expression of cellulases and xylanases genes in lactobacilli is mainly described in silage starter and the probiotic bacteria, L. plantarum, while little information is known about the other probiotic bacteria, L. bulgaricus (Bates et al., 1989; Scheirlinck et al., 1990).

Clostridium thermocellum, a gram-positive thermophilic anaerobe, secretes a highly potent and thermostable cellulase complex (Cornet et al., 1983). 10
The cel A gene codes for a previously purified endoglucanase (1,4-[3-D-glucan glucanohydrolase EC 3.2.1.4.), endoglucanase $A$, which has a MW of 56,000 and is one of the major endoglucanases secreted by $C$. thermocellum (Petre et al., 1981).

In this study, we expressed the $C$. thermocellum endoglucanase gene in $L$. plantarum and $L$. bulgaricus and also examined probiotic characteristics such as acid and bile-salt tolerances and antibiotic susceptibility using these genetically modified lactobacillus strains.

\section{П. MATERIALS AND METHODS}

\section{Bacterial strains, plasmids, and media}

Escherichia coli MC 1061 (Casadaban and Cohen, 1980) was used as a host for the construction of recombinant expression vectors. $L$. bulgaricus KCTC 3188 and L. plantarum KCTC 1048 were used as hosts for endoglucanase expression. Plasmids pCT104 (Beguin et al., 1985) and pNZ123 (de Vos et al., 1992) were used for the construction of recombinant expression vector. Lactobacilli were cultivated in MRS media (Difco) at $37^{\circ} \mathrm{C}$. Lactobacillus transformants were selected on MRS plates with $0.5 \% \quad \mathrm{CMC}$ (carboxymethyl cellulose) solidified with $1.5 \%$ agar. Antibiotics were amended with $10 \mathrm{\mu g} / \mathrm{ml}$ chloramphenicol $(\mathrm{Cm})$ were amended to select of lactobacilli transformant and the maintenance of plasmid.

\section{Isolation of plasmid DNA and DNA manipulation}

Standard methods, as described by Maniatis et al. (1982) were used for recombinant DNA work. Isolation of plasmid DNA from Lactobacilli was carried out according to the method of O'Sullivan and Klaenhammer (1993). 


\section{Transformation of Lactobacilli and E. coli}

Transformations of $L$. bulgaricus and $L$. plantarum were carried out by electroporation according to the method of Bates et al. (1989). Transformation of $E$. coli was also done through electroporation or the $\mathrm{CaCl}_{2}$ treatment method (Maniatis et al., 1982).

\section{Preparation of total lactobacilli cell ex- tracts}

The endoglucanase activity of each lactobacillus cell culture was estimated by dividing into two fractions of culture supernatant and whole-cell extract. The 16-h culture broth was centrifuged at $8,000 \mathrm{~g}$ for $20 \mathrm{~min}$ at $4^{\circ} \mathrm{C}$. The Harvested cells were washed twice with $50 \mathrm{mM}$ sodium citrate buffer ( $\mathrm{pH}$ 6.0), suspended in the buffer, and sonicated for $20 \mathrm{~min}$ with the Fisher scientific sonic dismembrator Model 550. Cell debris was removed from the extract by centrifugation for 15 $\min$ at $9,000 \mathrm{~g}$.

\section{Determination of endoglucanase activity}

For the qualitative detection of endoglucanase synthesis, congo red dye method was used (Teather and Wood, 1982). Enzyme assays were carried out in $50 \mathrm{mM}$ sodium citrate buffer $(\mathrm{pH}$ 6.0) containing $0.5 \%$ CMC. After incubation for $30 \mathrm{~min}$ at $60^{\circ} \mathrm{C}$, boiling for $10 \mathrm{~min}$ stopped the reaction mixture. The reducing sugar produced was measured by the DNS (dinitrosalicyclic acid) reagent (Miller et al., 1960). One unit (U) of enzyme activity was defined as that forming 11)mole of glucose equivalent of reducing sugar per minute under the given conditions. Specific activity was defined as units per milligram of protein. Protein concentration was determined by the Bradford method (1976).

10

\section{Proteinases inactivation test of cellu- lases}

The selection of small intestinal proteinaseresistant cellulase was carried out using the method of Hall et al.(1993).

\section{Determination of acid tolerance}

MRS broth was adjusted to $\mathrm{pH} 2$ and 3 by the addition of sterile $0.1 \mathrm{~N} \mathrm{HCl}$. Overnight lactobacillus cells were collected by low speed centrifugation at $5,000 \mathrm{~g}$ for $5 \mathrm{~min}$, rinsed once with phosphate buffered saline (PBS: $\mathrm{pH}$ 7.2) and $0.9 \% \mathrm{NaCl}$, and suspended in $2 \mathrm{~mL}$ PBS. Test tubes containing $\mathrm{pH}$-adjusted MRS broth at pH 2 and 3 were inoculated with the bacterial suspensions to achieve a final cell concentration of $10^{8} \mathrm{CFU} / \mathrm{mL}$. All tubes were incubated at $37^{\circ} \mathrm{C}$ for $2 \mathrm{~h}$. Populations were determined at $20 \mathrm{~min}$ intervals using MRS agar pour plates during $48 \mathrm{~h}$ incubation at $37^{\circ} \mathrm{C}$.

\section{Determination of bile-salt tolerance}

Lactobacilli MRS broth was prepared with 0.3 and $1 \%$ oxgall (Difco) dispensed in $30 \mathrm{ml}$ volumes and sterilized by autoclaving at $121^{\circ} \mathrm{C}$ for $15 \mathrm{~min}$. For each culture tested, one tube of each medium was inoculated with $0.3 \mathrm{ml}$ of freshly prepared overnight lactobacilli culture. The inoculated media were incubated in a $37^{\circ} \mathrm{C}$ water bath for $6 \mathrm{~h}$. Growth was determined in terms of the increases of $\mathrm{OD}_{600}$ with a spectrophotometer.

\section{Antibiotic susceptibility test}

Antibiotic susceptibility patterns of Lactobacilli were assayed using the disc diffusion method (Charteris et al., 1998a) as described previously using eleven antibiotic-impregnated paper discs 
(Difco). The results were expressed in terms of resistance, moderate susceptibility or susceptibility according to the interpretative standards (Charteris et al., 1998a).

\section{RESULTS AND DISCUSSION}

To develop recombinant Lactobacillus strains having capacity to hydrolyze cellulose in the small intestine, the secreted cellulase must not be inactivated by proteinases of pancreatic origin. Hall et al. (1993) previously reported that endoglucanase $\mathrm{E}$ from $C$. thermocellum was completely resistant to small intestinal proteinases. Similar results were also obtained in our study. Endoglucanase A from $C$. thermocellum was also most resistant to inactivation by small intestinal proteinases such as elastase, trypsin, and pancreatin (Table 1).

For the expression of endoglucanase gene in $L$. bulgaricus and L. plantarum, recombinant plasmid was constructed using E. coli $\mathrm{MC1061}$ as a host. A 3.2-kb Hind III fragment containing full-length celA gene from pCT104 was introduced into a promoterless Lactobacillus-E. coli shuttle vector pNZ123, resulting in pSD1 (Fig 1).

Table 1. Resistance of cellulases to proteolytic inactivation

\begin{tabular}{lccc}
\hline & \multicolumn{3}{c}{$\begin{array}{c}\text { Half life of enzyme incubated } \\
\text { with proteinase (min) }\end{array}$} \\
\cline { 2 - 4 } Enzymes $^{\mathrm{a}}$ & Pancreatin & Trypsin & Elastase \\
\hline \hline Endoglucanase A & 120 & $>110$ & $>60$ \\
Endoglucanase II & 30 & 20 & 15 \\
Endoglucanase B & 60 & 60 & 60 \\
Mixed-glucanase & 10 & 8 & 8 \\
CMC-xylanase & 5 & 6 & 5 \\
\hline a Endoglucanase A (Beguin et al., 1985), II (Min et \\
al., 1994), and B (Fugino and Ohmiya, 1991) were \\
derived from Clostridium thermocellum, Actinomyces \\
KNG 40, and Clostridium josui, respectively. Mixed- \\
glucanase (Teather and Erfle, 1990) and CMC- \\
xylanase (Woo, 1995) were derived from Fibrobacter \\
succinogenes.
\end{tabular}

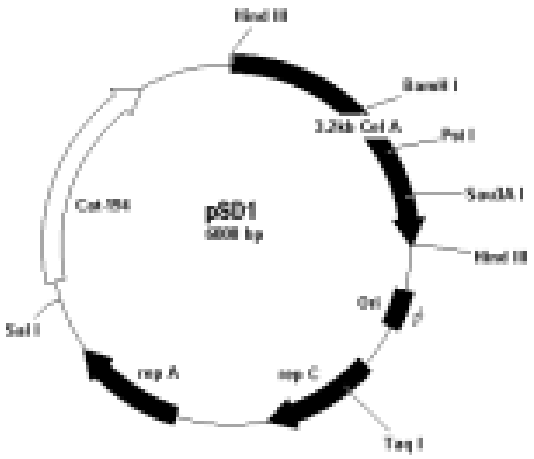

Fig 1. Lactobacillus expression plasmid harboring the $C$. thermocellum cel A gene.

The recombinant plasmid pSD1 was transformed into E. coli $\mathrm{MC} 1061$ through the $\mathrm{CaCl}_{2}$ competent cell method, and transformants showing endoglucanase activity were detected with Congo Red dye (data not shown). pSD1 was then electrotransformed into $L$. bulgaricus and $L$. plantarum. The electroporation efficiencies of $L$. bulgaricus and L. plantarum were $6.4 \times 10^{1}$ and $2.4 \times 10^{2} \quad \mathrm{CFU} / \mathrm{Mg}$ of $\mathrm{pSD} 1$ plasmid DNA, respectively (Table 2 ).

To investigate whether $L$. bulgaricus and $L$. plantarum harboring the recombinant plasmid pSD1 showed endoglucanase activity, the cells were cultured in MRS plate containing CMC and chloramphenicol. When the colonies on the plate were treated with Congo Red, halo zones indicating endoglucanase activity were formed (Fig 2). The specific enzyme activities of

Table 2. Electroporation efficiencies of plasmids transformed into $L$. bulgaricus and L. plantarum

\begin{tabular}{lc}
\hline \multicolumn{1}{c}{ Strains or plasmids } & Efficiency $^{\mathrm{a}}(\mathrm{CFU} / \mathrm{Mg})$ \\
\hline \hline L. bulgaricus $(\mathrm{pNZ123})$ & $1.2 \times 10^{2}$ \\
L. bulgaricus $(\mathrm{pSD} 1)$ & $6.4 \times 10^{1}$ \\
L. plantarum (pNZ123) & $8.0 \times 10^{2}$ \\
L. plantarum (pSD1) & $2.4 \times 10^{2}$ \\
\hline
\end{tabular}

${ }^{a}$ Average of two experiments. 


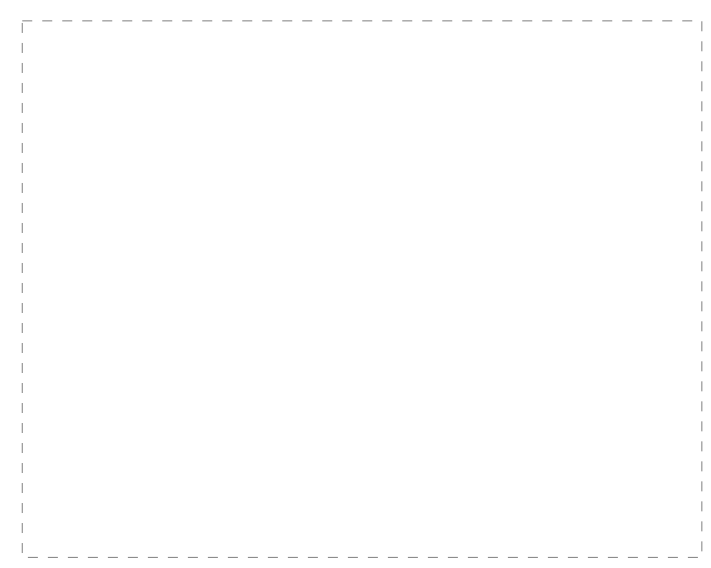

Fig 2. Congo-red test of Lactobacillus transformants indicating endoglucanase activity.

A : L. bulgaricus (pSD1)

B : L. plantarum (pSD1)

transformed E. coli, L. bulgaricus, and $L$. plantarum were $1.20,4.28$, and $6.36 \mathrm{U} / \mathrm{mg}$ of protein, respectively. The levels of cel $A$ expression in $L$. bulgaricus and $L$. plantarum compared to those of cellulases expressed by other Lactobacillus species were relatively high. Micromole quantities of glucose equivalents were released by hydrolysis of CMC compared to nanomole quantities of $L$. reuteri reported proviously. Also, most endoglucanases were secreted into extracellular fraction, both in $L$. bulgaricus and L. plantarum (Table 3). This result provides further evidence for the universal nature of signal peptide recognition by gram-positive bacteria (Bates et al., 1989), suggesting that the endoglucanase signal peptide of $C$. thermocellum is efficiently recognized by the protein transport machinery of $L$. bulgaricus and L. plantarum.

Both L. bulgaricus and L. plantarum were evaluated to be acid-tolerant. Viable counts of both of the strains were maintained at $\mathrm{pH} 3$ for at least $120 \mathrm{~min}$ (Fig 3). Acid-tolerant strains are thought to be more capable to survive at low $\mathrm{pH}$ conditions in the stomach (even at $\mathrm{pH} 2.0$ in extreme cases), where hydrochloric and gastric acids are secreted. Toit et al.(1998) reported that L. reuteri BFE 1058 and L. johnsonii BFE 1061 isolated from pig faeces were able to grow at $\mathrm{pH} 3$ and 4 and may thus be regarded as acidtolerant. Generally, intrinsic acid resistances of $L$. delbruelkii supsp. bulgaricus and $S$. thermophilus are poor, whereas L. acidophilus and bifidobacteria have been reported to be more resistant, although great differences exist between strains (Charteris et al., 1998b; Conway et al., 1987; Klein et al., 1998).

The growth curves of $L$. bulgaricus and $L$. plantarum in the presence of 0.3 and $1 \%$ oxgall were presented in Fig 4. At $3 \mathrm{~h}$ incubation, $L$. bulgaricus was greatly inhibited in MRS broth with oxgall, but $L$. plantarum was relatively bilesalt resistant. Bile salt tolerance is important for Lactobacillus strains to grow and survive in the upper small intestine; non-intestinal bacteria such as $L$. bulgaricus and L. lactis were very sensitive to bile concentrations lower than $0.05 \%$ (Gillinand and Speck, 1977; Toit et al., 1998).

Probiotics have been considered as substitutes of feed antibiotics, but, in some cases, it may be

Table 3. The activity of endoglucanase in transformants of $L$. bulgaricus and $L$. plantarum

\begin{tabular}{ccccc}
\hline \multirow{2}{*}{ Strain (Plasmid) } & Secretion Rate & \multicolumn{3}{c}{ Endoglucanase activity $^{\mathrm{a}}(\mathrm{U} / \mathrm{ml})$} \\
\cline { 3 - 5 } & $(\%)$ & Total & Supernatant & Whole cell extract \\
\hline \hline L. bulgaricus(pSD1) & 94.5 & 0.127 & 0.120 & 0.007 \\
L. plantarum(pSD1) & 91.7 & 0.157 & 0.144 & 0.013 \\
\hline
\end{tabular}

${ }^{a}$ One unit $(\mathrm{U})$ of enzyme activity was defined as that forming 1/amole of glucose equivalent of reducing sugar per minute under the given conditions. 


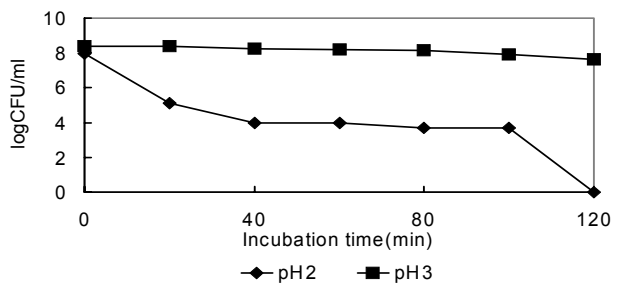

(A)

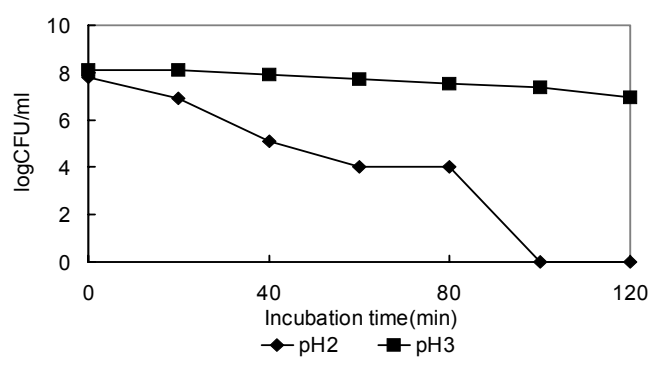

(B)

Fig 3. Survival of L. bulgaricus KCTC 3188 and L. plantarum KCTC 1048 in MRS broth adjusted to $\mathrm{pH} 2$ and 3 with $0.1 \mathrm{~N} \mathrm{HCl}$.

A : L. bulgaricus

B : L. plantarum

feasible to combine the probiotic and antibiotic treatments to obtain extra advantages (Nemcova et al., 1997). L. bulgaricus and L. plantarum showed a rather homogenous resistant pattern to antibiotics (Table 4). Both strains were resistant to amikacin, gentamicin, streptomycin, kanamycin, and colistin, while susceptible to penicillin G, amphicillin, tetracyclin, oxytetracyclin, and erythromycin. Dutta and Devriese (1981) investigated the minimal inhibitory concentrations of some commonly used feed antimicrobial agents against lactobacilli isolated from pigs, cattle, and poultry. The pencentages of resistant strains varied in pigs, cattle, and poultry ranging from 2,10 , and 8 to 70,95 , and 83 , respectively, according to the type of antibiotics, this suggest a potential for combined treatment of antibiotics and lactobacilli probiotics (Dutta and Devriese, 1981). 10

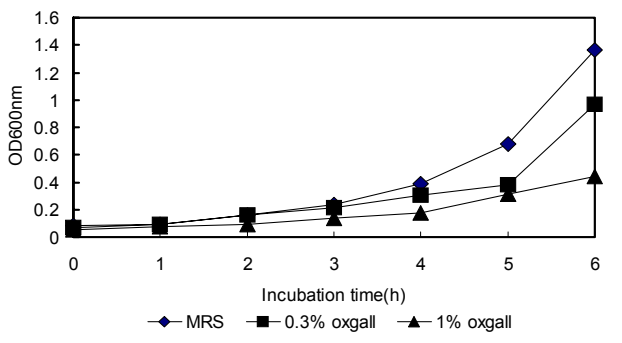

(A)

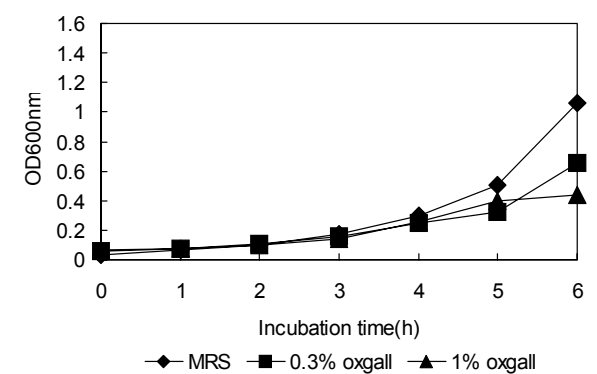

(B)

Fig 4. Survival of L. bulgaricus KCTC 3188 and L. plantarum KCTC 1048 in MRS broth with 0.3 and $1 \%$ oxgall.
A : L. bulgaricus
B : L. plantarum

Table 4. Responses of $L$. bulgaricus and $L$. plantarum to antibiotics

\begin{tabular}{lccc}
\hline Antibiotics & $\begin{array}{c}\text { Concen- } \\
\text { tration }\end{array}$ & $\begin{array}{c}\text { L. } \\
\text { bulgaricus }\end{array}$ & $\begin{array}{c}\text { L. } \\
\text { plantarum }\end{array}$ \\
\hline \hline Penicillin G & $10 \mathrm{unit}$ & ${ }^{\mathrm{a}} \mathrm{MS}$ & $\mathrm{MS}$ \\
Ampicillin & $10 \mathrm{mcg}$ & ${ }^{\mathrm{b}} \mathrm{S}$ & $\mathrm{MS}$ \\
Kanamycin & $30 \mathrm{mcg}$ & ${ }^{\mathrm{c}} \mathrm{R}$ & $\mathrm{R}$ \\
Streptomycin & $10 \mathrm{mcg}$ & $\mathrm{R}$ & $\mathrm{R}$ \\
Erythromycin & $15 \mathrm{mcg}$ & $\mathrm{S}$ & $\mathrm{S}$ \\
Amikacin & $30 \mathrm{mcg}$ & $\mathrm{R}$ & $\mathrm{R}$ \\
Tetracycline & $30 \mathrm{unit}$ & $\mathrm{S}$ & $\mathrm{S}$ \\
Bacitracin & $10 \mathrm{unit}$ & $\mathrm{MS}$ & $\mathrm{R}$ \\
Colistin & $10 \mathrm{mcg}$ & $\mathrm{R}$ & $\mathrm{R}$ \\
Oxytetracycline & $30 \mathrm{mcg}$ & $\mathrm{S}$ & $\mathrm{S}$ \\
Gentamycin & $10 \mathrm{mcg}$ & $\mathrm{R}$ & $\mathrm{R}$ \\
\hline
\end{tabular}

${ }^{a}$ MS : Moderately susceptible.

${ }^{\mathrm{b}} \mathrm{S}$ : Susceptible.

${ }^{\mathrm{c}} \mathrm{R}$ : Resistant. 
Morever, the occurrence of bacitracin-resistant $L$. acidophilus strains from cattle and poultry was related to the bacitracin used as a growth promoter in these animals (Charteris et al., 1998).

In conclusion, this study provides important findings concerning a probiotic species of lactobacilli. First, the expression of an endoglucanase gene of heterologous origin was demonstrated for the first time in L. bulgaricus. Second, the probiotic properties of $L$. bulgaricus and L. plantarum were described (such as, acid tolerance, bile-salt tolerance, and antibiotic susceptibility). These results may provide useful basic information to employ lactobacilli in genetic modification for biotechnological application.

\section{IV. 적 요}

다양한 미생물들로부터 유래한 cellulase 중에 서, 특히 장내 단백질 가수분해효소에 안정한 Clostridium thermocellum 균주 유래의 endoglucanase를 선별하였다. 그 후 그 유전자의 자체 프로모터에 의해 발현되는 재조합 Lactobacillus 용 발현벡터를 구축하였고, 그 발현벡터를 $\mathrm{pSD} 1$ 이라 명명하였다. 이 발현벡터를 L. bulgaricus 와 L. plantarum 균주에 각각 전기천공법을 이 용하여 형질전환시키는데 성공하였으며 그 재 조합 균주들로부터 endoglucanase 효소역가를 조사한 결과 각각 배지 상층액에서 $0.12,0.144$ $\mathrm{U} / \mathrm{ml}$ 로 조사되었다.

한편 이들 균주들의 생균제로 갖추어야할 특성 인 내산성, 내담즙성 및 항생제내성 여부를 조사 한 결과, 이들 균주들은 모두 $\mathrm{pH} 3$ 과 같은 산성 조 건하에서도 안정하였으며, 내담즙성에 있어서는 특히 L. plantarum 균주의 경우 $0.3,1 \%$ 의 oxgall에 서도 안정하였다. 또한 항생제 내성을 조사한 결 과 두 균주 모두 amikacin, gentamicin, kanamycin, colistin에 저항성이 높은 것으로 나타났다.

\section{ACKNOWLEDGEMENTS}

This work was supported by the Brain Korea 10
21 project and the research project of Science and Technology Policy Institutes (STEPI) in Korea. We thank Dr. De Vos for providing Lactobacillus expression vector.

\section{REFERENCES}

1. Abe, F., Ishibashi, N. and Shimamura, S. 1995. Effect of administration of bifidobacteria and lactic acid bacteria to newborn calves and piglets. J. Dairy Sci. 78:2838-2846.

2. Bates, E. M., Gilbert, H. J., Hazzlewood, G. P., Huckle, J., Laurie, J. I. and Mann, S. P. 1989. Expression of a Clostridium thermocellum endoglucanase in Lactobacillus plantarum. Appl. Environ. Microbiol. 55:2095-2097.

3. Beguin, P., Cornet, P. and Aubert, J. P. 1985. Sequence of a cellulase gene of the thermophilic bacterium Clostridium thermocellum. J. Bacteriol. 162: 102-105.

4. Bradford, M. 1976. A rapid and sensitive method for quantification of microgram quantities of protein utilizing the principle of protein-dye binding. Anal. Biochem. 72:248-254.

5. Casadaban, M. and Cohen, S. N. 1980. Analysis of gene control signals by fusion and cloning in Escherichia. J. Mole Biol. 138:179-207.

6. Charteris, W. P., Kelly, P. M., Morelli, L. and Collins, J. K. 1998a. Antibiotic susceptibility of potentially probiotic Lactobacillus species. J. Food Prot. 61:1636-1643.

7. Charteris, W. P., Kelly, P. M., Morelli, L. and Collins, J. K. 1998b. Development and application of an in vitro methodology to determine the transit tolerance of potentially probiotic Lactobacillus and bifidobacterium species in the upper human gastrointestinal tract. J. Appl Microbiol. 84:759-768.

8. Conway, P. L., Gorbach, S. L. and Goldin, B. R. 1987. Survival of lactic acid bacteria in the human stomach and adhesion to intestinal cells. J. Dairy Sci. 70:1-12.

9. Cornet, P., Miller, J., Beguin, P. and Aubert, J. P. 1983. Characterization of two cel(cellulose degradation) genes of Clostridium thermocellum coding for endoglucanases. Biotech. 1:589-594.

10. de Vos, W. M., Siezen, R. J. and Kuipers, O. P. 1992. Lantibiotics similar to nisin A. PCT Patent Application WO, 92/18633.

11. Dutta, G. N. and Devriese, L. A. 1981. Sensitivity and resistance to growth promoting agents in animal lactobacilli. J. Appl Bacteriol. 51:283-287.

12. Fujino, T. and Ohmiya, K. 1991. Cloning of the 
cel B gene encoding 1,4-B-glucanase-2 from Clostridium josui in Escherichia coli and the properties of the translated product. Appl. Environ. Microbiol. 72:422-425.

13. Gillinand, S. E. and Speck, M. L. 1977. Antagonistic action of Lactobacillus acidophilus forward intestinal and foodborne pathogens in associative culture. J. Food Prot. 40:820-823.

14. Hall, J., Ali, S., Surani, M. A., Hazlewood, G. P., Clark, A. J., Simon, J. P., Hilst, B. H. and Gilbert, H. J. 1993. Manipulation of the repertoire of digestive enzymes secreted into the gastrointestinal tract of transgenic mice. Biotech. 11:376-379.

15. Heng, N. C. K., Jenkinson, H. F. and Tannock, G. W. 1997. Cloning and expression of an endo-1,3-1, 4-B-glucanase gene from Bacillus macerans in $\mathrm{L}$ actobacilli reuteri. Appl. Environ. Microbiol. 63:3 336-3340.

16. Klein, G., Pack, A., Bonaparte, C. and Reuter, G. 1998. Taxonomy and physiology of probiotic lactic acid bacteria. Int. J. Food Microbiol. 41:103-125.

17. Maniatis, T., Fritsch, E. F. and Sambrook, J. 1982. Molecular cloning: a laboratory manual. Cold Spring Harbor Laboratory, Cold Spring Harbor, New York.

18. Miller, G. L, Blum, R., Glennon, W. E. and Burton, A. L. 1960. Measurement of carboxymethylcellulase activity. Anal. Biochem. 1:127-132.

19. Min, H. K., Choi, Y. J., Cho, K. K., Ha, J.K. and Woo, J. H. 1994. Cloning of the endoglucanase gene from Actinomyces sp. 40 in Escherichia coli and some properties of the gene products. J. Microbiol. Biotech. 4:102-107.

20. Nemcova, R., Laukova, A., Gancarcikova, S. and Kastel, R. 1997. In vitro studies of porcine lactobacilli for probiotic use. Berl Munch Tierarztl Wochenschr
110:413-417.

21. O'Sullivan, D. J. and Klaenhammer, T. R. 1993. Rapid mini-prep isolation of high quality plasmid DNA from Lactococcus and Lactobacillus spp. Appl. Environ. Microbiol. 59:2730-2733.

22. Petre, J., Longin, R. and Miller, J. 1981. Purification and properties of an endo- $\$$-1,4-glucanase fro $\mathrm{m}$ Clostridium thermocellum. Biochime 63:629-639.

23. Scheirlinck, T., de Meutter, J., Arnaut, G., Joos, H., Claeyssens, M. and Michiels, F. 1990. Cloning and expression of cellulase and xylanase genes in Lactobacillus plantarum. Appl. Microbiol. Biotech. 33:534-541.

24. Tannock, G. W. 1992. Genetic manipulation of gut microorgainsm. In: Fuller P(eds) Probiotics. London, United kingdom, the scientific basis Chapman \& Hall, p181-207.

25. Teather, R. M. and Erfle, J. D. 1990. DNA sequence of a Fibrobacter succinogens mixed-linkage glucanase gene. Appl. Environ. Microbiol. 172:3837-3841.

26. Teather, R. M. and Wood, P. J. 1982. Use of congo red-polysaccharide interactions in enumeration and characterization of cellulolytic bacteria from the bovine rumen. Appl. Environ. Microbiol. 43:777-780.

27. Toit, M. D., Franz, C. M. A. P., Dicks, L. M. T., Schillinger, U., Haberer, P., Warlies, B., Ahrens, F. and Holzapfel, W. H. 1998. Chracterisation and selection of probiotic lactobacilli for preliminary minipig feeding trial and their effect on serum cholesterol levels, faeces $\mathrm{pH}$ and faeces moisture content. Int. J. Food Microbiol. 40:93-104.

28. Woo, J. H. 1995. Gene cloning and biochemical chracterization of cellulase and xylanase from anaerobic rumen bacteria. Korea. Ph.D. Thesis. p67-77.

(접수일자 : 2003. 3. 14. / 채택일자 : 2003. 6. 1.) 